\title{
The Integration of the Armenian Immigrants in István Lakatos's Siculia
}

\author{
Levente PAP \\ Sapientia Hungarian University of Transylvania (Cluj-Napoca, Romania) \\ Department of Humanities \\ paplevente@uni.sapientia.ro
}

\begin{abstract}
The relatively short history of the Transylvanian Principality (one hundred and fifty years or so) was full of unexpected changes. From the tragic Battle of Mohács, fought against the Ottoman invasion (1526), until the Diploma Leopoldinum, which integrated the Principality in the huge Habsburg Empire, events like the rise of Lutheran, Calvinian or Unitarian reforms, the Catholic Reformation or Counter-Reformation despite the Edict of Torda in 1568, which declared religious tolerance and freedom of conscience - brought forth more disagreements. In the 1670s a new population coming from Moldova appeared in the Principality: the Armenians. The history of the establishment of this population was mentioned by the Catholic priest István Lakatos in his work Siculia (1702). Through the analysis of this work, we search for answers to the question regarding the relatively short integration period of this ethnic group.
\end{abstract}

Keywords: Armenians, integration, immigrants, Siculia, István Lakatos, Transylvanian Principality.

The political weight of the Transylvanian Principality growing weaker and, at the same time, the pressure from the Habsburg Empire getting stronger made it more and more obvious that the Principality, which had preserved its independence for one hundred and fifty years by means of successful political maneuvres and appropriate international diplomacy, could no longer maintain its independent status. The Diploma Leopoldinum, issued in 1690, which in spite of having again put into force the old Transylvanian laws, recognizing the system of three nations and four denominations codified by the legislation, once and for all determined the fate of the independent Principality. After the death of Michael I Apafi, Prince of Transylvania, in December 1691, Leopold I issued the reformulated version of the Diploma, in which, however, the confirmation of the elected Prince Michael II Apafi was not included. He charged the Gubernium, constituted in Hermannstadt (Sibiu, Nagyszeben) in 1691, with the administration of Transylvania, while 
later, in 1693, in Vienna, the Court Chancery for Transylvania was set up, and thus the Principality gradually got under Habsburg authority losing its former independence. At the Court of Vienna the shape which the status of Hungary and the Principality of Transylvania was to take within the bounds of the Monarchy had been a serious matter even in the years before the Diploma. The policy that the Habsburg administration applied in the new territories was mainly determined by a document entitled Einrichtungswerk des Königreichs Hungarn, drawn up by the committee whose head was count Lipót Kollonich (Varga J. and Kalmár 2010). The major interest of the Court of Vienna was that the economy of each newly annexed land should rise to the level of the Austrian lands and be able to support itself in this respect. A possible solution to make the economy prosper was considered to be the repopulation of deserted territories. The migration from the marginal regions of the Hungarian Kingdom towards the territories of the Hungarian Plain and South-Transdanubia opened the possibility for ethnic groups from the border regions of the Carpathian Basin (Slovenians, Croatians, Slovaks, Serbians, Ruthenians, Romanians) to immigrate to the country. The spontaneous immigration and movements of population were not a solution to the demographic problems (Varga J. 1999, 42-43). The Court intended to deal with this problem in its own manner: by deliberately settling Germans from the Holy Roman Empire to the territories of the Hungarian Kingdom. However, every settling process had in sight one very important consideration: regarding the division of denominations, it aimed to increase the proportion of the Catholic population. This could partly be achieved by the settlement of Catholic ethnic groups (Swabians), or by obligatorily converting people of other denominations first of all, Romanians, Ruthenians and Serbians of Orthodox Rite - to Catholicism (Nagy 2013a, 58-74). ${ }^{1}$ Although these principles were, above all, valid for the territory of the Hungarian Kingdom, since in Transylvania the system of three nations and four religions recognized by law had been preserved, even here the religious policy was shaped according to this law. At Monarchy level, the importance of the pursuit of such religious policy was especially enhanced by the fact that the Catholic population, loyal both to Rome and to the Habsburg Court, was much easier to govern. Since, at that time, no notable Armenian community lived on the territory of the Hungarian Kingdom (unlike in Transylvania), the Habsburg administration did not deal with their situation in particular.

From the territory of the Armenian kingdoms that lost their independence in the eleventh century due to the invasion of the Seljuk Turks and the Mongolians, an exodus of population started, and it continued in the fourteenth-fifteenth centuries. At that time the larger part of the emigrating population found refuge in Poland and Moldavia (Lukácsy 1859, 63-65; Nistor 1912, 55-57; Kovács

1 The Habsburg administration recognized the freedom of worship of the Lutherans and the Reformed, but also urged their assimilation into the Catholic church. 
2012, 22-23). Armenians came to Transylvania as early as the fourteenth century, they were mostly spice traders coming from the Balkans. ${ }^{2}$ The Saxons of Transylvania, holding monopoly over the greatest part of the commercial and craft market, did not like the Armenian traders being present in growing numbers in the Principality; therefore, they got the Diet to apply negative discrimination against the traders from the Levant. Despite all these measures, more and more Armenian traders came to Transylvania on the commercial route from the Levant as well as from Moldavia. These traders brought their merchandise mostly to the markets of Marosvásárhely (Târgu Mureş) and Gyergyószentmiklós (Gheorgheni) (Nagy 2013a, 81-88). New, larger groups of Armenian immigrants arrived in Transylvania, in Szeklerland, in 1668 and later in 1672. They had two reasons for choosing Transylvania as the destination of their flight: on the one hand, they were familiar with the market conditions in the Principality, on the other hand, they had knowledge about the pluralistic policy of religion in Transylvania (Nagy 2013a, 81). ${ }^{3}$ The Armenians arriving to Transylvania showed up in larger masses in the Principality at a time that can be called fortunate, for Prince Michael I Apafi was attempting to break the trade monopoly of the Transylvanian Saxons and the Greeks precisely with the help of the Armenians' trading activity. This is proven by the fact that, in order to prevent the resettling of the Armenians in Moldavia, on 25 October 1680, he granted them free trade and settlement right hoping that in this way he would contribute to the boosting of the home economy of the Principality (Nagy 2013a, 84; cf. Pál 1997). The Armenians as an immigrating ethnic group are present in historiography as early as the end of the seventeenth century. Concerning them, we are provided with relevant data from the historical work entitled Siculia, written in Latin by the Szekler historiographer István Lakatos (Pap 2017). ${ }^{4}$

István Lakatos (1635?-1706) was an educated Catholic priest and dean of Alcsík, born in Székelyudvarhely (Odorheiu Secuiesc), one of the illustrious representatives of the Catholic ecclesiastical renewal movement in Csík district. He was educated at the Jesuit College in Kolozsvár (Cluj-Napoca) and, as we presume, in Nagyszombat (Trnava) and Vienna, where he studied theology and was ordained. He recorded in writing the events of Thököly's invasion that took place in Alcsík, as well as the constitutions of the parish church of Csíkkozmás (Cozmeni), which had earlier been published in the Szekler Archives (1897, 424-

2 We also know about their church or a smaller congregation. In Tolmács community near the town of Nagyszeben (Sibiu) the inscription of a seal dating from 1355, on which we can read the name of a certain Armenian bishop called Márton as well as the name of a local parish, was discovered: "Martini Episcopi Armenorum de Tolmachy, sigillum parochiae Armenorum" (Zimmerman, Werner and Müller 1902, 106-107).

3 The new, immigrating Armenian ethnic groups avoided Poland for the very reason of the unionist endeavours carried out by force.

$4 \quad$ For the nineteenth-twentieth century relations see Ajtony (2013). 
445). Among his historical works by far the best is Siculia, which he himself dated to 1702, but which, according to evidence, had been accessible for reading earlier, before the year 1699 (Pap 2017, 163).

The Hungarian academic historiography surely had an impact on our author, since the outstanding professor of the institution where he had presumably studied, Gábor Hevenesi, was an important representative of the Catholic renewal movement and the modern source-collecting school. Despite that, the work was originally written with the intention of giving a description of Szeklerland, and it also became, we could rather say, an early Catholic prototype of the history of Transylvanian reformation.

Right at the beginning of his work, Lakatos - according to the tradition of historiography - presents the region the history of which he would later discuss, and it is here that he talks about the different ethnic groups inhabiting this land in his time, as well as about those populations which had formerly lived here. He also makes mention of the Romanians, the Dacians and the Getae, highlighting the following:

It is only the Szekler nation that has remained pure throughout history, not mixing with other ethnic groups, although, for the most part, these have their settlements close to the Szeklers, the Transylvanian Saxons are their neighbours on their own settlements, while, on the other side, the Romanians, in the east the Moldavians and in certain parts the Wallachians, all these Romanians being the descendants of the Romans. Openly, however, they have never mixed with these in religion, marriages and morality. Among them it is the Romanians only that do, for a living, shepherding, their villages, just like the villages of the Transylvanian Saxons, are situated separately from theirs. They consider the Armenians, who arrived in this region not long ago, mostly with the intention of trading, foreigners. (Lakatos qtd. in Pap 2017, 19)

What is interesting about the fragment quoted above is that the author does not only mention the three nations recognized by law, but beside the Romanians, he writes about the Armenians as well. Lakatos is very reticent in relating about the Transylvanian Saxons, the reason for him to do so is the obstinacy of the Saxons to continue to hold firm to Protestantism. Thus the author could not have presented them, in any way, as positive participants, and in the given historical situation speaking ill of the population with a German native tongue was not entirely a wise thing. The author does not give a detailed account of the Hungarians either. After the decline of the reign of the protestant Princes of Transylvania, as a

$5 \quad$ Fragments from István Lakatos's Siculia quoted in this article were translated from Latin by the author of this article. 
consequence of the increase of the Baroque Habsburg influence, the Catholics could benefit from an ever greater political support:

the star of the Roman Catholic Church has risen and has started to shine more and more brightly over Transylvania together with Szeklerland. The native inhabitants did not dare to boast too much about this matter for the reason that, during the reign of the Transylvanian Princes, who had succeeded each other on the throne for almost a whole century, everywhere in the towns and villages of Transylvania it was Calvinism, most of all, that had prospered, while in the towns of the Transylvanian Saxons Lutheranism had struck root. (Lakatos qtd. in Pap 2017, 81-82)

The above statements prove that the Armenians were considered immigrating foreign elements. Despite this, however, in comparison with the other ethnic groups, the author devotes long paragraphs to the presentation of the history of Armenians in Transylvania.

Lakatos, who himself was an eyewitness of the Armenians' settlement in Szeklerland, emphasizes, above all, church-related matters. He mentions that

[d]uring the year 1670 the Armenians from Moldavia established settlements in Transylvania, most of them settling in Szeklerland, in Gyergyószentmiklós (Gheorgheni) and Csíkszépvíz (Frumoasa) and beside these, in the following villages: Görgény (Gurghiu), Petele (Petelea), Felfalu (Suseni) and Remete (Remetea), which count as important Szekler territories, and further, in Beszterce (Bistrița), headed by bishop Minas, together with the members of the clergy, they set up their seat achieving from the Principality the right of free movement with the purpose of trading. The Armenians were obliged to pay taxes, as a consequence, the Principality appointed from among the Armenians a mayor who had the same rights as a mayor in his own country, Armenia. However, he was submitted to the chief government official in charge of the Szekler districts. (Lakatos qtd. in Pap 2017, 83)

Lakatos could have had access to sources pertaining to the history of Armenians in Transylvania thanks to the connections with his contemporaries as well as his own life and work experience as a priest in Csík district - first in Csíksomlyó (Şumuleu Ciuc) (?-1684) and then in Csíkkozmás (Cozmeni) (1684-1706) - for many decades having worked in the same deaconry, on the land where the Armenians of Csíkszépvíz (Frumoasa) had settled. At that time there were only very few written sources in connection with the history of the Armenians. One of the earliest and, at the same time, most reliable sources was written 
by the unionist bishop Stefano Stefanowicz Roszka, ${ }^{6}$ Armenian of Poland, an ecclesiastical history yearbook that did not yet exist in Lakatos's time. ${ }^{7}$

In Hungarian historiography the conditions for critical history were formed in the seventeenth-eighteenth centuries. The appearance of the Jesuit source-collecting schools counted as a milestone both in Hungarian (Transylvanian) and European historiography. The Hungarian branching off of the European school can be linked to the University of Nagyszombat (Trnava) founded by Péter Pázmány (Szögi 1985). In the second half of the seventeenth century, the Rector of this University, Gábor Hevenesi (and the Jesuit Sámuel Timon) started a program to collect documents, diplomas, correspondence and other sources that were relevant for the history of the Catholic Church. Hevenesi built a real network of people who helped in the work of source-collecting in the whole country, including Transylvania. Many of these were his former disciples, alumni of the institution of Nagyszombat. Among them was Rudolf Bzensky (Molnár 2007), a Jesuit priest who had been to Transylvania many times and had even done source collecting work on Hevenesi's instruction. Besides collecting sources, the Jesuit pater had his own domains of interest, namely the bishopric of Milkó (Milcov) and, as a special interest, the nations and denominations of Transylvania. In 1694 he compiled a mission report in which he presented the nations and denominations of Transylvania, among which we find the Armenians, too, Bzensky dealing with this subject in other works as well. He makes use of authentic first-hand information about the Armenians that he had probably received from Oxendius Virziraski. ${ }^{8}$

Lakatos and Bzensky were personally acquainted and were familiar with each other's work; this is something that Bzensky himself mentioned in his writing

"Stefan (Stefano) Stefanowicz Roszka, titular bishop of Hymeria, an Armenian historian of Poland. Roszka also had very strong connections in Transylvania: in 1672, together with his parents, he fled from Poland (from Kameniec Podolski) to Beszterce (Bistrița), Transylvania, and it is there that he, at a young age, began his church activity as a Christian of Apostolic Creed, under the protection of bishop Minas Zilifdarean. At the turn of the years 1720-30 he went on several visitations to the Armenian parishes in Transylvania on the instructions of the Holy See. During his visitations in Transylvania, in order to reinforce the religious life of the local Armenian communities, he founded so-called religious bodies. He established such bodies (fellowships, confraternities, for which the Armenian word is elbayrut'iwnk) in the towns of Szamosújvár (Gherla) and Gyergyószentmiklós (Gheorgheni)” (Nagy 2013a, 19, translated by me, L. P.).

7 This work speaks about the events up to the year 1730 .

8 "Oxendio Virziresco was born in the town of Botoşani, Moldavia, in 1654. In 1676, influenced by the missionaries working in Moldavia, he converted to Catholicism following which he started his theological studies at Collegio Armeno in Lemberg. On the recommendation of Francesco Martelli, nuncio of Warsaw, he went to Rome, where he pursued his studies in theology at Collegio Urbano. In 1678 he was ordained and, in the same year, he went from Rome to Lemberg to continue his studies, and then there he obtained a degree in theology (vardapetut'iwn). After this he returned to Rome, where he was engaged at Propaganda Fide. The letter Nersesowicz wrote to him in September 1684 found him already in the Eternal City, from where, the next year, at the request of the bishop, the Holy See posted him to Transylvania on a mission among the Armenians living there" (Nagy 2013a, 108, translated by me, L. P.; cf. Nagy 2013b). 
entitled Syllogimaea sive Collectanea Ecclesiae Transylvanae Libri Septem, dated $1699,{ }^{9}$ the manuscript of which has survived to our days. The author does not simply refer to Lakatos, but he cites from the Siculia, word by word, the part concerning the description of the Szeklers. There is sure evidence for the professional contacts of the two; presumably, Lakatos might have written the part about the Armenians based on the information he had received from Bzensky. To support the probability of this statement it is important for us to mention that the report written to Hevenesi outlines the religious conditions of the Armenians of Transylvania starting from their settlement up to the time when Oxendius was ordained bishop (Nagy 2013a, 18). In Lakatos's work, too, the part concerning the Armenians ends with the description of Oxendius being ordained bishop by popular request (Pap 2017, 86).

As for Lakatos, we can presume the existence of another possible source regarding bishop Oxendius and the confessional conditions of the Transylvanian Armenians. The fact that the Edict of Torda (Turda) of 1568, which proclaimed the freedom of conscience but, beside the equality of religions, forbade that the papists should have a bishop, drew attention to the awkward situation of the Principality of Transylvania, which had granted pluralism of religion. In order to solve the ever threatening problems of a Catholic Church without a bishop, starting with Prince Gabriel Bethlen, the Catholic Church was headed by priests and vicars invested with the authority of a bishop, appointed by the Prince (Szekfú 1983, 177-178). During the reign of Prince Michael I Apafi, Bertalan Szebelébi, a Franciscan friar was presented vicar of Transylvania. Bertalan Szebelébi was on good terms with Lakatos and the appreciative statements in Siculia are evidence of this, while it is of no minor importance that it was Szebelébi who, as a witness, had confirmed the deed issued by Lakatos.

Lakatos paid special attention to Oxendius's personality and work of unification:

But in 1684, on his return from Rome, Oxendius Virziraski, who had come from the Armenian episcopate of Moldavia and had been, previously, impregnated with the deviations of those and who in the meantime leaving his parents, since 1670, for fourteen years had devoted his life to do studies at Collegium Urbanum in Rome, the educational institution belonging to the Missionary Congregation, and who, in the building of the Holy Office, having rejected his own errors, was ordained and sent back to the same diocese, as Apostolic missionary, by the Missionary Congregation, that is the holy congregation of the cardinals who were at the head of the faith

9 "Incidi opportune Mense Julio Anni 1696 in familiarem conversationem A. R. P. Stephani Lakatos, in Csik, Siculiae Parochi, Doctrina tum sacra, tum profana multum illustris, cujus scripta Historica perlegens reperi quoque mirabilia aliqua ad fecunditatem Transylvaniae Terrae pertinentia, eademque his meis Prolegomenis inferre non dubitavi ejusdem nomine” (Bzensky 1699, fol 26). 
spreading mission. Here Oxendius, or spelled Auxentius, shed light upon the misconceptions in the faith of the Armenians, for it was him who had received the chapels ceded from them, and in those he conducted the Catholic service of his own mission, according to the Armenian rituals, and he did this work in such a manner that, as a result of his efforts, in four years, there were sixty families who having rejected their false beliefs, converted to the obedience of the Apostolic See. Moreover, he persuaded bishop Minas to confess his faith before Honourable Cardinal Pallavicini, archbishop of Warsaw, and he did so, upon his return to Transylvania, absolved from his sins, and there he passed away in God. His priests and the people of his diocese unanimously asked for the union with the Roman Catholic Church, hence, for that purpose, they sent Reverend Illés, archbishop and Armenian priest, together with eight more people, to Lemberg (Lviv), where they, on behalf of the entire diocese, swore obedience to the Pope. All those who had been absolved from their sins requested that the previously mentioned Oxendius should be ordained bishop for them. This was accomplished and since then God has sustained, in peculiar ways, his devout work done for the development of his church, whenever he publicly did and still does, in the town of Beszterce (Bistrița) and other places, his holy activity of a bishop, whenever needed, and, according to unanimous opinions, in a praiseworthy manner, for the consolation of many, both Armenians and others. (Lakatos qtd. in Pap 2017, 84-86)

Even if not always the most accurate, ${ }^{10}$ biographical information sheds favourable light on the Armenian bishop. The Catholic community of Transylvania could also be grateful to Oxendius, for he himself also took part in giving religious assistance to the Szeklers. Lakatos indicates this fact dimly in the last line of the quotation above, when he mentions that the unionist Armenian bishop is conducting a most blissful activity "for the consolation of many, both Armenians and others."

A question remains interesting further on, namely the reason why the author pays so much attention to the community of Armenians. We find the answer in the opus below:

for almost a whole century, during the reign of the Calvinist Princes of Transylvania, who succeeded each other on the throne, in the towns and villages of Transylvania it was Calvinism that prospered, while in the towns of the Transylvanian Saxons the Lutheranism struck root, in Kolozsvár (ClujNapoca) and Szeklerland Arianism, while through the foreigners, it was the Holy Roman Catholic Church that developed. (Lakatos qtd. in Pap 2017, 82)

10 Oxendius only arrived in Transylvania in 1685, and he had had discussions with cardinal Pallavicini much earlier (Nagy 2013a, 92). 
As we have seen before, at the end of the seventeenth century radical political changes took place in Transylvania, as the Principality was slowly losing its independence. This also created a new religious situation, because the new administration fully supported the interests of the Catholics, as this was true for the Hungarian Kingdom as well. Although the conditions of the Catholics had improved, these were far from being bright, as it was obvious from Oxendius's reports. In the new situation, the Catholic party was in a schizophrenic state: partly, it would have liked to take the most advantage from the change of administration and overcome the Protestants, who otherwise outnumbered them. This direction also fully corresponded with the general aspirations of the Court of Vienna, the hallmark of which was the missionary work of the Jesuits by the unification of smaller Christian ethnic groups (e. g. the Romanians). On the other hand, the clergy assisting the Catholic Szeklers living in one block was not happy to participate in this work, the newly presented bishop who was actually residing here could not accept others to interfere in his jurisdiction. Despite this, Siculia, a historical work probably intended to be read by a large public, would have liked to meet the requirements of the current political situation and thus to highlight the imperishable merits of the Szeklers, who were loyal to the Catholic Church, as they had taken stand for their Catholic faith even in dangerous times - and, of course, then, in the new political system, they deserved to be given preference. But all this did not happen according to their calculations, namely, the Habsburg Court did not totally import the Hungarian recipe, but preserving the previous system, played off the nationalities and religions against one another and tried to gain more and more influence in the new province, in which the leading class was still the Protestant nobility, while the Protestant congregation outnumbered the other denominations.

However, as Lakatos himself stated, the Szeklers considered the Armenians newcomers, yet they did not view them as people to be excluded from society. The reason for this, on the one hand, was the fact which we mentioned previously, namely that the Armenians managed to fill an economic gap in the Szeklers' social system. On the other hand, the constraint of the possibility of union or unification made the Armenian community interesting in the eyes of the Catholic Church. Despite the fact that the Catholic clergy of Szeklerland did not consider the conversion of the different communities, among them the Romanians, to Catholicism to be a major task, bishop Martonfi was not pleased with the fact that the Armenian bishopric was included in the plan of Rome to unify the Armenians. According to this plan, he was supposed to oversee this process of unification. The realistic policy still suggested that the Armenian community that had moved to the country only a few decades earlier could be used to increase the number of the Catholics in Transylvania, thus enhancing the possibility that the interests of the Szeklers should be better asserted at the Habsburg Court. Lakatos himself was 
characterized by a certain duality: he did not support, in practice, the unification of the different nationalities, but still, in his official discourse he declared opinions that made him famous and which fully corresponded with the official endeavours of the Habsburg court, and by which he could present the Transylvanian Catholic Church and the Szeklers in a suitable light to the new administration.

\section{Works Cited}

Ajtony, Zsuzsanna. 2013. "Erdélyi örmények magyar szemmel." [“Transylvanian Armenians in Hungarian Eyes.”] In Kulturális identitás és alteritás az idóben [Cultural Identity and Alterity in Time], eds. Judit Pieldner, Levente Pap, Zsuzsa Tapodi, Péter Forisek and Klára Papp, 163-170. Debrecen: Debreceni Egyetemi Történelmi Intézete.

Bzensky, Rudolf. 1699. Syllogimaea sive Collectanea Ecclesiae Transylvanae Libri Septem. Batthyaneum Library. MS. no.VI. 10. 6.

Kovács, Bálint. 2012. "Örmények Erdélyben (A 17. századi letelepedéstől a 20. századig)." ["Armenians in Transylvania (From Their Settlement in the Seventeenth Century to the Twentieth Century).”] Erdélyi Örmény Gyökerek [Armenian Roots in Transylvania] vol. 17, no. 185-186: 22-29.

Lukácsy, Christophorus. 1859. Historia Armenorum Transsilvaniae a primordiis usque nostram memoriam e fontibus authenticis et documentis antea ineditis elaborata. Viennae: Typis Congregationis Mechitharisticae.

Molnár, Antal. 2007. "Bzensky Rudolf jezsuita történetíró és az erdélyi örmények." ["The Jesuit Historiographer Rudolf Bzensky and the Transylvanian Armenians."] In Örmény diaszpóra a Kárpát-medencében [Armenian Diaspora in the Carpathian Basin], eds. Sándor Őze and Bálint Kovács, 1828. Piliscsaba: Pázmány Péter Katolikus Egyetem Bölcsészettudományi Kar Történettudományi Intézet.

Nagy, Kornél. 2013a. Az erdélyi örmények katolizációja (1685-1715). [The Catholicisation of the Armenians in Transylvania (1685-1715).] Budapest: MTA Történettudományi Intézet.

Nagy, Kornél. 2013b. "The Church-Union of the Armenians in Transylvania." In Far away from Mount Ararat, 17-27. Leipzig: Leipziger Universitätsverlag.

Nistor, I. Ion. 1912. Handel und Wandel in der Moldau. Bis zum Ende des 16. Jahrhunderts. Czernowitz: K.K. Universitätsbuchhandlung H. Pardini.

Pál, Judit. 1997. "Az erdélyi örmény népesség számának alakulása és szerkezete a 18. században." ["The Evolution of the Number and the Structure of the Transylvanian Armenian Population in the Eighteenth Century."] Erdélyi Múzeum vol. 59, no. 1: 104-120. 
Pap, Levente, ed. 2017. Lakatos István: Siculia. Trans. into Hungarian and commented by Levente Pap. Cluj-Napoca: Transylvanian Museum Society.

Szekfú, Gyula. 1983. Bethlen Gábor. [Gabriel Bethlen.] Budapest: Helikon.

Székely Oklevéltár. [Szekler Archives.] vol. VI. 1897. ed. Lajos Szádeczky. ClujNapoca: Ajtai K. Albert.

Szögi, László. 1985. A budapesti Eötvös Loránd Tudományegyetem rövid története 1635-1985. [The Short History of Eötvös Loránd University in Budapest, 16351985.] Budapest: Eötvös Loránd Tudományegyetem Tudományszervezési Osztálya.

Varga J., János. 1999. “A bécsi kormányzat telepítés- és valláspolitikája Magyarországon a századfordulón.” ["The Settlement and Religious Policy of the Court of Vienna in Hungary at the Turn of the Century."] In Relații interetnice în zona de contact româno-maghiaro-ucraineană din secolul al XVIII-lea până in prezent [The Relation of the Romanian, Hungarian and Ruthenian Ethnic Groups from the Eighteenth Century to the Present Day], eds. Hans Gehl and Viorel Ciubotă, 41-50. Satu Mare - Tübingen: Editura Muzeului Sătmărean.

Varga J., János and Kalmár, János, eds. 2010. Einrichtungswerk des Königreichs Ungarn (1688-1690). Stuttgart: Franz Steiner Verlag.

Zimmermann, Franz, Carl Werner and Georg Müller, eds. 1902. Urkundenbuch zur Geschichte der Deutschen in Siebenbürgen. Vol. III. Sibiu: Verein für siebenbürgische Landeskunde. 